\title{
Олена Ільєнко
}

кандидат філологічних наук, доцент, завідуюча кафедрою іноземних мов Харківського національного університету міського господарства імені О. М. Бекетова, Харків, Україна E-mail:lenailyenko@yahoo.com

\section{ЗМІСТ НАУКОВО-МЕТОДИЧНОЇ СИСТЕМИ ФОРМУВАННЯ КОНКУРЕНТОСПРОМОЖНОГО ФАХІВЦЯ МУНІЦИПАЛЬНОЇ ЕКОНОМІКИ ТА ЕТАПИ ЇЇ РЕАЛІЗАЦІї}

Анотація: Метою статті є на підставі аналізу літератури з проблем обтрунтування змісту науково-методичної системи формування конкурентоспроможного фахівия муніципальної економіки, етапи їі реалізаиії, а також мету $і$ завдання для кожного з них. Визначено різнищю у розумінні понять «система формування конкурентоспроможного фахівия», яка є відкритою, синергетичною, динамічною, $i$ «педагогічна система формування конкурентоспроможного фахівия», що є спеціально організованою, иільовою, иілісною, прогностичною, такою, що реалізується в умовах середовища підготовки фахівия. У статті виокремлено та схарактеризовано такі етапи реалізації науково-методичної системи як пропедевтичний, діагностичний, змістово-діяльнісний та результативний.

Ключові слова: науково-методична система, етапи реалізаиї науково-методичної системи, конкурентоспроможній фахівець, конкурентоспроможність.

\section{Olena Ilienko}

Candidate of Philological Sciences, Associate Professor, Head of the Department of Foreign Languages of the Kharkiv National University of Municipal Economy named after A. M. Beketov, Kharkiv, Ukraine E-mail:lenailyenko@yahoo.com

\section{CONTENT OF THE SCIENTIFIC AND METHODICAL SYSTEM FOR TRAINING OF A COMPETITIVE PROFESSIONAL OF MUNICIPAL ECONOMY AND THE STAGES OF ITS IMPLEMENTATION}

\begin{abstract}
The aim of the article is on the basis of the literature analysis to substantiate the content of the scientific and methodical system for training of a competitive professional of municipal economy, the stages of its realization as well as the goals and tasks for each of them. The difference in the interpretation of such concepts as "the system for training of a competitive professional", which is an open, synergistic, dynamic one and "the pedagogical system for training of a competitive professional" is determined. The latter system is considered as a specially organized, purposeful, holistic, prognostic phenomenon, which is realized in the conditions of the training environment of a professional. The article highlights and describes the stages of implementation of the scientific and methodical system as propaedeutic, diagnostic, content-activity and resulting.
\end{abstract}


Key words: scientific and methodical system, stages of the scientific and methodical system implementation, competitive specialist, competitiveness.

\title{
Елена Ильенко
}

\section{СОДЕРЖАНИЕ НАУЧНО-МЕТОДИЧЕСКОЙ СИСТЕМЫ ФОРМИРОВАНИЯ КОНКУРЕНТОСПОСОБНОГО СПЕЦИАЛИСТА МУНИЦИПАЛЬНОЙ ЭКОНОМИКИ И ЭТАПЫ ЕЕ РЕАЛИЗАЦИИ}

\begin{abstract}
Аннотация: Целью статьи является обоснование на основе анализа литературь содержания научно-методической системы формирования конкурентоспособного спещиалиста муниципальной экономики, этапов ее реализации, а также целей и задач каждого из них. Определена разница в трактовке таких понятий как «система формирования конкурентоспособного специиалиста», которая является открытой, синергетической, динамичной, и «педагогическая система формирования конкурентоспособного специалиста», которая является специально организованной, целенаправленной, целостной, прогностической, т.е. такой, которая реализуется в условиях среды подготовки специалиста. $B$ статье выделены и охарактеризованы такие этапы реализации научно-методической системы как пропедевтический, диагностический, содержательно-деятельностный и результативный.
\end{abstract}

Ключевые слова: научно-методическая система, этапы реализации научнометодической системы, конкурентоспособный специалист, конкурентоспособность.

\section{Olena Ilienko}

An extended abstract of a paper on the subject of:

\section{"Content of the scientific and methodical system for training of a competitive professional of municipal economy and the stages of its implementation"}

The article focuses on the content of the scientific and methodical system for training of a competitive professional of municipal economy and the stages of its implementation. The aim of the article is on the basis of the literature analysis to substantiate the content of the scientific and methodical system for training of a competitive professional of municipal economy, the stages of its realization as well as the goals and tasks for each of them.

The difference in the interpretation of such concepts as "the system for training of a competitive professional", which is an open, synergistic, dynamic one and "the pedagogical system for training of a competitive professional" is determined. The latter system is considered as a specially organized, purposeful, holistic, prognostic phenomenon, which is realized in the conditions of the training environment of a professional. The implementation of the pedagogical system for training professionals, in particular, students in the field of municipal economy, can be considered as a stage of the development of competitiveness as a personal and professional formation. The pedagogical system is viewed as a subsystem of the general system of competitiveness formation of a university graduate, and, therefore, the highest 

МАЙБУТНІХ СПЕЦІАЛІСТІВ

of the possible levels of competitiveness manifestation, in the opinion of the author, can be observed only among the professional who has already realized the professional potential (akme-ideal). It is noted that within the university the akme of the future professional competitiveness can be evaluated only as the highest level of the subsystem"pedagogical system of forming the competitiveness of a future professional" (acme-prognostic)

Three main stages are considered to be necessary for pedagogical systems, which have the following goals: 1. formation of positive attitude among subjects of the educational process, interest in a certain problem, setting on a particular activity with a specific purpose, awareness and acceptance of its goals, etc .; 2. formation of special competences, as well as personal qualities necessary for solving a specific scientific problem; 3. evaluation and reflection of the activities in the context of a particular problem. The requisite to distinguish the propaedeutic stage of the system's implementation is noted, within which the activities of the teachers involved should be coordinated for the process of a certain formation development as well as the academic curriculum that will allow

Постановка проблеми в загальному вигляді та іiі зв'язок із важливими науковими чи практичними завданнями. Ефективна професійна підготовка майбутнього конкурентоспроможного фахівця передбачає обгрунтування та впровадження науково-методичної системи, що є неможливим без розкриття іiї змісту та етапів реалізації.

Аналіз останніх досліджень і публікацій, у яких започатковано розв'язання цієї проблеми і на які спирається автор. Для визначення змісту науково-методичної системи формування конкурентоспроможного фахівця муніципальної економіки слід зробити поглиблений аналіз суті поняття «сис- organizing pedagogical influence on the subjects of study. In addition, it is pointed out that the diagnostic stage of the system manifestation needs a special organization, which should be focused on studying the level of awareness of the problem by specific participants in the experiment and studying the initial level of competitiveness formation among the students. The tasks of the diagnostic stage of the scientific and methodical system should be, respectively, to identify the diagnostic tools, specify the criteria and indicators of the competitiveness formation of the future professionals of the municipal economy, select methods for identification of the existing level of the competitiveness formation. The article highlights and describes the stages of implementation of the scientific and methodical system as propaedeutic, diagnostic, content-activity and resulting.

Thus, the idea of the content of the scientific and methodical system of forming $a$ competitive professional of municipal economy and the stages of its realization, namely, propaedeutic, diagnostic, content-activity and effective, is the basis for the experimental realization of the system in the conditions of the university's educational environment.

тема». Згідно з філософським словником, [5] слово «система» означає «ціле, що складене із частин».

Системний підхід до дослідження певного поняття або процесу найбільш грунтовно представлено у працях О. Іонової, Ю. Козловського, О. Резван, Л. Сушенцевої, Л. Штефан [ 2, 3, 7, 9, 11].

У дослідженні О. Іонової система визначається множинністю елементів, що знаходяться у відношеннях і зв'язках один із одним і утворюють певну цілісність, єдність [2]. Цікавий підхід до визначення формальної сторони поняття «система» представлено Л. Штефан [11]. Дослідниця за- 
пропонувала експлікувати аналіз повторюваності одиниць термінологічної інформації у різних наукових джерелах, на основі чого було визначено, що системою можна вважати множину елементів (компонентів), поєднаних зв'язками, при цьому автор вважає випадковим поняття «комплекс» у визначенні системи.

На основі грунтовного аналізу праць дослідників, О. Резван узагальнює ознаки соціальної системи як особливого виду систем:

- досліджуваний об’єкт як система повинен бути представлений певною сукупністю частин або компонентів. У своїй взаємодії вони утворюють єдине ціле, яке може бути розділене певним способом, від цього буде залежати обмеженість певного елемента;

- система повинна мати інтегративні властивості, які не зводяться до властивостей окремих іiі компонентів;

- будь-яка система має певну внутрішню організацію - структуру, яка виявляється в установленні зв'язків між компонентами;

- цілісна система вибірково взаємодіє з середовищем. Така взаємодія може порізному сприяти функціонуванню системи: iii розвитку, зміцненню, стабілізації або стриманню іiі руху та інтегративних процесів [ 7 с. 182-183].

Підтримуючи дослідницю у таких висновках, зауважуємо, що система формування конкурентоспроможності фахівця має ознаки соціальної, оскільки основна діяльність 3 перетворення особистості, що реалізується у певному середовищі, $\epsilon$ затребуваною соціумом, адже конкурентоспроможність наразі є якістю, без якої фахівець не може бути успішним у житті.

У дослідженні Ю. та І. Козловських акцентується увага на інтегрованих властивостях об'єкта дослідження - їх походженні, зв'язках та структурі. Вчені визначають особливості застосування системного підходу представниками гуманітарних наук, до яких зокрема належить педагогіка. Так, науковці-гуманітарії часто приписують собі системний підхід тоді, коли просто оперують поняттям «система». Звісно, що системні методи застосовуються при вивченні поведінки, функцій, дій, а тому застосовувати цей термін до просторового об'єкта або предмета $є$ неприпустимим. Актуалізуючи увагу на тому, що система є не просто сумою певних елементів, а передбачає появу нової якості, дослідники зауважують про важливість «спільних закономірностей цієї якості, що не видимі в кожному елементі системи, але керують ними, як рука пальцями» [3 с. 164]. Отже, йдеться про певне злиття функцій всіх елементів системи, в результаті чого актуалізується нова якість, на формування якої й спрямована вся система. Прикладом зазначеного можна вважати ситуацію, наведену I. Козловською у монографії «Едукаційна інтегрологія»: «під час обговорення питання у науковому колективі знаходиться рішення чи нове знання, яке не прийшло на думку жодному із членів колективу окремо (знання колективу $\epsilon$ більшими, ніж сума знань його членів)». Отже, можна вважати, що функція роботи системи в цілому є ефективнішою, аніж сума ефективності функцій окремих іiі елементів. Зазначена характеристика системи $\epsilon$ цінною для усвідомлення організації процесу формування конкурентоспроможного фахівця муніципальної економіки, оскільки ми маємо враховувати, що кожна частина системи у поєднанні із іншими іiі частинами прогностично дасть більший ефект, ніж тоді, коли вона розглядатиметься окремо від цих інших частин.

Виділення не вирішених раніше частин загальної проблеми, котрим присвячується дана стаття. На підставі вищезазначеного у дослідженні виокремлено такі етапи реалізації науково-методичної сис- 
теми професійної підготовки майбутнього конкурентоспроможного фахівця муніципальної економіки:

- пропедевтичний;

- діагностичний;

- змістово-діяльнісний;

- результативний.

Завданнями діагностичного етапу науково-методичної системи відповідно мають бути: визначення діагностичного інструментарію, уточнення критеріїв і показників рівнів сформованості конкурентоспроможності майбутнього фахівця муніципальної економіки, добір діагностик для виявлення наявного рівня сформованості його конкурентоспроможності відповідно до її структурних компонентів, що виокремлено нами вище.

На цьому етапі відбувається запровадження методів анкетування, тестування, опитування, спостереження, а також самодіагностики й самоаналізу - що реалізовувались у групових та індивідуальних формах засобами діагностики (анкетами, тестами, опитувальниками тощо).

Отже, дослідження змісту науковометодичної системи формування конкурентоспроможного фахівця муніципальної економіки та етапи іiі реалізації не були до цього об'єктом уваги дослідників, тому $є$ основою для експериментальної реалізації системи в умовах навчального середовища університету.

Формулювання цілей статті (постановка завдання). Метою статmі передбачено на підставі аналізу наукової літератури $з$ проблеми обгрунтувати зміст та етапи реалізації науково-методичної системи формування конкурентоспроможного фахівця муніципальної економіки у вищому технічному навчальному закладі.

Виклад основного матеріалу дослідження 3 повним обгрунтуванням отриманих наукових результатів. У поясненні концепції роботи системи формування кон- курентоспроможного фахівця, зокрема муніципальної економіки, слід орієнтуватись на іii багатошаровість. Конкретний рівень досягнення конкурентоспроможності може бути сформований у певному середовищі, але загалом досягнення акме конкурентоспроможності особистості відбувається упродовж іiї активного професійного самовиявлення у різних середовищах. Саме тому ми не можемо дослідити процес формування зазначеного утворення у межах реалізації особистості у фаховому середовищі.

Система формування конкурентоспроможності фахівця також є такою, що розвивається, при цьому розвиток здійснюється на різних їі рівнях.

У межах освітнього середовища особистість набуває якості конкурентоспроможності через педагогічний вплив на iї мотивацію, загально професійні та фахові компетенції, рівень здатності до рефлексії тобто на компоненти, які в цілому виявляють іiі рівень. Зазначений процес може відбуватись як природно - без спеціального втручання факторів впливу, так і організованим способом, коли створюється система впливу на особистість 3 метою актуалізації iii самовдосконалення на основі певного змісту (у нашому випадку - конкурентоспроможності). Саме тоді проектується й реалізується певна система, що містить мету, принципи, цільові етапи та засоби впливу на особистість, критеріальнопоказникову базу сформованості прогнозованого утворення; у межах системи в цільовому аспекті координується діяльність педагогів, зміст програми підготовки фахівців, форми педагогічного супроводу тощо. Результатом реалізації будь-якої педагогічної системи стає якісне перетворення особистості суб'єктів іiі впливу (у нашому випадку - студентів), що корелюється за змістом із її цільовим призначенням.

Однак зауважуємо, що формування конкретного особистісного утворення, зок- 
рема конкурентоспроможності, не завершується у межах одного середовища. Активізуючи розвиток майбутнього фахівця в аспекті його конкурентоспроможності у межах університетського середовища, ми запускаємо механізм його саморозвитку за зазначеним змістом у межах фахового середовища, в якому він буде реалізовуватись. Отже, акме результатів впливу системи формування конкурентоспроможності можна очікувати не лише від іiі реалізації у межах університету, а й передусім від самовиявлення особистості як конкурентоспроможного фахівця у професійному середовищі. Тому реалізацію самої такої системи у межах підготовки фахівців, зокрема муніципальної економіки, можна розглядати як етап формування конкурентоспроможності у контексті особистіснопрофесійного утворення.

Отже, визначаємо різницю у розумінні понять «система формування конкурентоспроможного фахівця», яка є відкритою, синергетичною, динамічною, незалежною від способів її організації, але залежною від ресурсів середовища та мотивації самого фахівця, i «педагогічна система формування конкурентоспроможного фахівця», що є спеціально організованою, цільовою, цілісною, прогностичною, такою, що реалізується в умовах середовища його підготовки (в університеті зокрема). Тоді педагогічну систему можна розглядати як підсистему загальної системи формування конкурентоспроможності фахівця. Отже, найбільш високий із можливих рівнів виявлення конкурентоспроможності, за нашою думкою, можна спостерігати лише у фахівців, що вже реалізовуються у професії (акме-ідеальне), тоді як у межах університету акме конкурентоспроможності майбутніх фахівців може бути оцінено як сформоване на середньому рівні системи і вищому рівні підсистеми «педагогічної системи формування конкурентоспроможності майбутньо- го фахівця», зокрема у галузі муніципальної економіки (акме-прогностичне).

3 метою уточнення змісту поняття «педагогічна система» було здійснено аналіз наукових праць. Так, у дослідженні приєднуємось до групи вчених [8], які вважають, що «педагогічна система - це полісистемне утворення (цілісність), що складається 3 багатьох взаємодіючих і взаємодоповнюючих частин» і підкреслюють, що «категорія «педагогічна система» та іiї модифікації («виховна система», «навчально-виховна система», «система освіти») - одна 3 основних в понятійному апараті педагогіки». Щодо суті та змісту цього поняття, то вони розмежовують його, вказуючи, що «у широкому розумінні педагогічна система - це:

- об'єднання учасників педагогічного процесу, в якому висувається педагогічна мета і розв'язуються педагогічні задачі;

- об'єднання учасників педагогічного процесу, де їх діяльність (пізнавальна, трудова, моральна, суспільно-політична, художньо-естетична, ігрова тощо) є джерелом педагогічної мети і засобом досягнення одночасно.

У вузькому розумінні педагогічна система - це:

- впорядкована кількість взаємопов'язаних компонентів, що утворюють єдине ціле і підпорядковані цілям виховання та навчання;

- соціально-обумовлена цілісність учасників педагогічного процесу з їх матеріальними й духовними цінностями, що взаємодіють на основі співробітництва між собою та $з$ навколишнім середовищем, котра спрямована на формування та розвиток особистості» [8, с. 649-650].

Таким чином, як стверджує О. Романовський [8], структура педагогічної системи може бути представлена як взаємопов'язана сукупність інваріантних елементів: учні чи студенти; мета навчання; зміст навчання; педагоги; дидактичні процеси; їх 
матеріально-технічне забезпечення; організаційні форми навчання. Н. Кузьміна [4] до структурних і функціональних компонентів відносить: мету, навчальну інформацію, засоби педагогічної комунікації, учнів, вчителів, результат.

У визначенні структурних компонентів педагогічної системи орієнтувались на результати дослідження О. Іонової [2]. Представляючи аналіз низки досліджень, автор узагальнює наукові підходи до визначення структурних компонентів будьякої педагогічної системи. Зокрема, у концепції Л. Спіріна визначаються такі компоненти: мета системи, підсистема, що управляє (педагог), підсистема, що управляється (вихованець), взаємодія й взаємини цих підсистем, зміст діяльності системи, продукти роботи системи; Л. Вікторова додає до визначених компонентів ієрархію рівнів системи; у працях Н. Кузьміної виокремлюються функціональні компоненти системи (гностичний, проектувальний, конструктивний, комунікативний, організаторський), що зумовлюють рух, розвиток, удосконалення педагогічної системи і внаслідок цього - стійкість, життєздатність, виживання.

Таким чином, узагальнюючи науково-педагогічні підходи до розуміння поняття «педагогічна система», визначаємо використання цього терміну в двох змістовних розуміннях: для визначення якісних станів педагогічних процесів або для позначення деяких педагогічних утворень.

Зважаючи на роль педагогічної системи у формуванні певного особистісного утворення, зауважуємо на необхідності урахування таких іiі аспектів:

- мети, концептуальних положень ii реалізації;

- $\quad$ середовища, в якому вона реалізується;

- методичного проектування та шляхів реалізації системи;
- прогностичних результатів іiі упровадження.

Отже, визначаємо, що для формування конкурентоспроможності майбутніх фахівців, зокрема муніципальної економіки, важливим стає урахування у системі як середовища, у якому буде відбуватись зазначений процес, так і наукових та методичних положень його організації. Отже, справедливим видається характеристика зазначеної системи як науково-методичної.

Цілі, що визначаються педагогічними системами, утворюють ієрархії. Зокрема, О. Новиков виділяє три рівні цілей:

- перший рівень цілей - соціальне замовлення суспільства, його різних соціальних груп усім системам освіти на певний суспільний ідеал особистості як людини, громадянина, професіонала;

- другий рівень цілей - це вже освітня мета для кожної освітньої програми, для кожного типу освітніх закладів окремо, де соціальне замовлення трансформується в поняттях і категоріях педагогіки;

- третій рівень цілей - це ті педагогічні цілі, які реалізуються повсякденно, на кожному занятті [6, с. 117].

Доходимо до переконання, що науково-методична система професійної підготовки майбутнього конкурентоспроможного фахівця муніципальної економіки також вимагає виявлення специфіки іiі мети, завдань, змісту, засобів, результату як провідних системоутворювальних блоків даної педагогічної системи, а їх реалізація потребує відбору ефективного технологічного забезпечення й критеріїв перевірки результативності.

Логічним видається визначення основної мети зазначеної науково-методичної системи - формування конкурентоспроможності майбутніх фахівців муніципальної економіки.

Реалізація науково-методичної системи формування конкурентоспроможності 
майбутніх фахівців муніципальної економіки потребує організації конкретних видів діяльності (наукової, методичної, мотиваційної, діагностичної, навчально-виховної, практичної, аналітичної) на конкретних етапах дослідження. У зв'язку з цим стає необхідним виокремлення й обгрунтування етапів зазначеної системи, а також визначення мети й завдань для кожного 3 них, форм і методів їх реалізації.

3 цією метою нами, передусім, було проаналізовано дисертаційні праці сучасних науковців, що стосуються різноманітних проблем професійної підготовки фахівців економічних та технічних галузей, аналіз яких виявився доцільним через представлення прикладів етапів реалізації різноманітних педагогічних систем.

Так, О. Ігнатюк у своїй системі підготовки майбутнього інженера до професійного самовдосконалення виокремлює початковий (спрямований на формування у студентів установки на особистіснопрофесійний розвиток та самовдосконалення у процесі професійного пізнання і самопізнання), процесуальний (формування у студентів професійних знань, умінь, навичок, розвиток особистісних якостей) та рефлексивно-оцінювальний (застосування отриманих знань, умінь, навичок при самостійній роботі під час професійної підготовки, виробничої практики тощо, аналіз та оцінювання процесу особистіснопрофесійного розвитку і самовдосконалення майбутніх інженерів) етапи[1].

У дослідженні проблеми формування професійно-рефлексивної позиції майбутніх фахівців автомобільно-дорожньої галузі О. Резван пропонує етапи реалізації системи iї формування: пропедевтичний (ознайомлення викладачів із концепцією рефлексивної позиції особистості; визначення дисциплін, в межах яких має здійснюватись педагогічний вплив на студентів 3 метою формування у них професійно- рефлексивної позиції), діагностикоцільовий (діагностика початкового ступеню сформованості професійно-рефлексивної позиції у майбутніх фахівців; визначення цілей та завдань дослідження), змістоводіяльнісний (здійснення технологічного процесу формування професійнорефлексивної позиції у студентів через активацію кожного із іiї компонентів) та самовдосконалення (спрямований на рефлексію причин проблем, що виникають у процесі досягнення професійних цілей) [7].

Розвиток професійної спрямованості особистості студентів технічних спеціальностей, представлений А. Швальовою у вигляді моделі, здійснюється через реалізацію цільового (здійснюється організація професійно орієнтованої освіти, що забезпечує розвиток професійної спрямованості особистості студентів технічних спеціальностей), змістово-технологічного (розкривається зміст, засоби і технології навчання, що забезпечують розвиток професійної спрямованості особистості майбутніх фахівців) та оцінно-результативного (відбувається оцінка рівня розвитку професійної спрямованості особистості студентів на основі їх показників) етапів [10].

Узагальнюючи вищенаведені підходи вчених, ми дійшли висновку, що обов'язковими для педагогічних систем $\epsilon$ три основні етапи, у межах яких виокремлюються цілі:

- формування у суб'єктів навчально-виховного процесу позитивного ставлення, інтересу до певної проблеми, установки на певну діяльність 3 конкретною метою, усвідомлення й прийняття іiі цілей тощо;

- формування спеціальних компетенцій, а також особистісних якостей, необхідних для вирішення конкретної наукової проблеми;

- оцінки та рефлексії діяльності в контексті певного питання. 
Водночас зауважуємо про необхідність виокремлення пропедевтичного етапу реалізації системи, у межах якого має бути скоординована діяльність викладачів щодо процесу формування конкретного утворення, а також визначено навчальний курикулум, який дозволятиме організувати педагогічний вплив на суб'єктів навчання. 3 викладачами дисциплін, залучених до експерименту, має бути узгоджено методи взаємодії у межах визначеної проблеми: розроблено для впровадження у програми дисциплін способи та прийоми, визначено час для здійснення цих способів, встановлено терміни координації проміжних та остаточних результатів взаємної діяльності.

Крім того, потребує особливої організації діагностичний етап, що має бути орієнтованим на дослідження рівня усвідо-

\section{Список літератури}

1. Ігнатюк, О. А. (2009) Формування готовності майбутнього інженера до професійного самовдосконалення: теорія і практика: монографія. Х. : НТУ «ХПІ»,432 с.

2. Іонова, О. М. (2011) Системний та синергетичний підходи у педагогічних дослідженнях : навчальний посібник. Х.:ХНПУ імені Г.С. Сковороди,. 50 с.

3. Козловський, Ю. М., \& Козловська, I. М (2015) Едукаційна інтегрологія: монографія. Львів : Сполом,360 с.

4. Кузьмина, Н. В.(1980) Методология системних исследований: учебное пособие. Львов:Изд-во ЛГУ, 172 с.

5. Грицанов, А. А. (2001) Новейший философский словарь: 2-е изд. Минск: Интерпрессервис; Книжный дом, 1280 с.

6. Новиков, А. М. (2005) Методология учебной деятельности. М.: Эгвес, 176 с.

7. Резван, О. О. (2014) Формування професійно-рефлексивної позиції майбутнього фахівця автомобільно-дорожньої галузі: монографія. Х.: «Точка»,400 с. млення проблеми конкретними учасниками експерименту та вивчення початкового рівня сформованості компонентів досліджуваного утворення у студентів.

Реалізація діагностичного етапу науково-методичної системи має здійснюватися у контексті констатувального етапу педагогічного експерименту.

Висновки 3 даного дослідження та перспективи подальших розвідок у даному напрямку. Отже, уявлення про зміст науковометодичної системи формування конкурентоспроможного фахівця муніципальної економіки та етапи іiі реалізації, а саме пропедевтичний, діагностичний, змістово-діяльнісний та результативний є основою для експериментальної реалізації системи в умовах навчального середовища університету.

8. Романовський, О. Г.,Пономарьов, О. С.,Гуревичов, М. М., \& Резнік,С. М. (2014) Оцінка конкурентоспроможності фахівця і якості його професійної підготовки: навч.-метод. посіб. Х.:НТУ «ХПИ»,68 с.

9. Сушенцева, Л. (2011) Формування професійної мобільності майбутніх кваліфікованих робітників у професійнотехнічних навчальних закладах : теорія i практика : монографія. Кривий Ріг: «Видавничий дім»,385 с.

10. Швалева, А. В. (2007) Развитие профессиональной направленности личности студентов технических специальностей :Дис. ... канд. пед. наукпо спец. 13.00.08 Оренбург, 219 с.

11. Штефан, Л. В. (2013) Теоретичні і методичні засади формування інноваційної культури майбутніх інженерів-педагогів у процесі професійної підготовки. Дис. на здобуття ступ. д. пед.наук зі спец. 13.00.04. $\mathrm{X} .: 535 \mathrm{c}$.

\section{References}

1. Ihnatiuk, O. A. (2009) Formuvannia hotovnosti majbutn'oho inzhenera do 
profesijnoho samovdoskonalennia: teoriia $i$ praktyka: monohrafiia. [ Formation of readiness of the future engineer for professional self-improvement: theory and practice: monograph]. Kh.: NTU «KhPI», 432s. [ in Ukrainian ]

2. Ionova, O. M. (2011) Systemnyj ta synerhetychnyj pidkhody u pedahohichnykh doslidzhenniakh : navchal'nyj posibnyk. [ System and synergistic approaches in pedagogical research: a manual. ] Kh.:KhNPU imeni H.S. Skovorody, 50 s. [ in Ukrainian ]

3. Kozlovs'kyj, Yu. M., \& Kozlovs'ka, I. M (2015) Edukatsijna intehrolohiia: monohrafiia. [ Edukatsionnaya integrologiya: monografiya. ] L'viv : Spolom, 360 s. [ in Ukrainian ]

4. Kuz'mina, N.V.(1980) Metodologija sistemnyh issledovanij: uchebnoe posobie [ Methodology of system studies: a study guide ] L'vov: Izd-vo LGU, 172 s. [in Russian]

5. Gricanov, A. A. (2001) Novejshij filosofskij slovar': 2-e izd. [ The newest philosophical dictionary: 2 nd ed. ] Minsk: Interpresservis; Knizhnyj dom, 1280 s. [in Russian]

6. Novikov, A.M. (2005) Metodologija uchebnoj dejatel'nosti. [ Methodology of educational activity.] M.: Jegves, 176 s. [in Russian]

7. Rezvan, O. O. (2014) Formuvannja profesijno-refleksivnö pozicii majbutn'ogo fahivcja avtomobil'no-dorozhn'oï galuzi: monografija. [ Formation of professionally reflexive position of the future specialist of the

Стаття надійшла до редколегї: 12.04.2018 automobile and road industry: monograph.] H.: «Tochka», 400 s. [ in Ukrainian ]

8. Romanovs'kyj, O. H., Ponomar'ov, O. S., Hurevychov, M. M., \& Reznik, S. M. (2014) Otsinka konkurentospromozhnosti fakhivtsia $i$ iakosti joho profesijnoi pidhotovky: navch.-metod. posib. [ Assessment of the competitiveness of a specialist and the quality of his professional training: teaching method. manual] Kh.:NTU «KhPY», 68 s. [ in Ukrainian ]

9. Sushentseva, L.(2011) Formuvannia profesijnoi mobil'nosti majbutnikh kvalifikovanykh robitnykiv u profesijnotekhnichnykh navchal'nykh zakladakh : teoriia $i$ praktyka : monohrafiia. [ Formation of professional mobility of future skilled workers in vocational schools: theory and practice: monograph.] Kryvyj Rih: «Vydavnychyj dim», 385s. [ in Ukrainian ]

10. Shvaleva, A. V. (2007) Razvitie professional'noj napravlennosti lichnosti studentov tehnicheskih special'nostej : Dis. ... kand. ped. nauk po spec. 13.00.08 [ Development of a professional orientation of the personality of students of technical specialties: Dis .... kand. ... cand. ped. sciences on spec. 13.00.08] Orenburg, 219 s. [in Russian]

11. Shtefan, L. V. (2013) Teoretychni $i$ metodychni zasady formuvannia innovatsijnoi kul'tury majbutnikh inzheneriv-pedahohiv $u$ protsesi profesijnoi pidhotovky. [ Theoretical and methodical principles of formation of innovative culture of future engineers-teachers in the process of professional training.] Dys. na zdobuttia stup. d. ped.nauk zi spets. 13.00.04. Kh.: 535 s. [ in Ukrainian ] 